\title{
(Re)Inserting charity in education
}

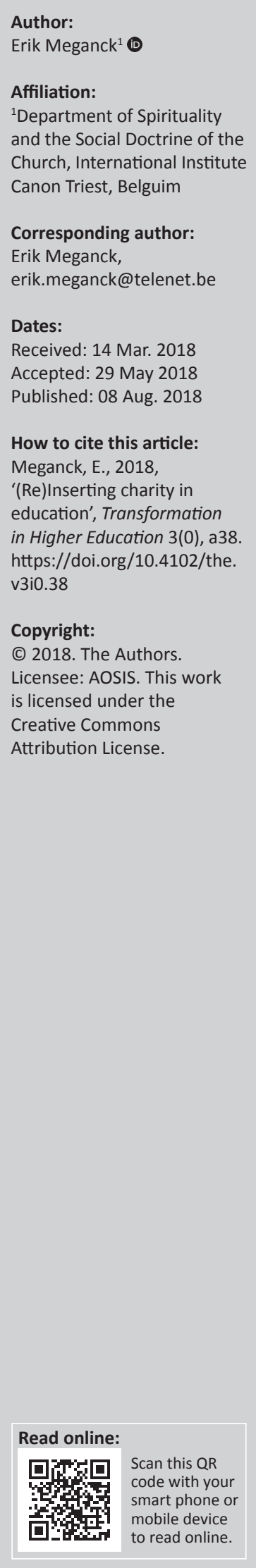

Background: Recently, charity (re)appears in cultural discourse. It is no longer confined to (moral) theology.

Objectives: The aim of this article is to defend the acceptance of charity as a major and fundamental category in the formulation of professional learning goals and in the transformation and development of curricula in higher education, using historical and philosophical arguments.

Methods: I first offer a philosophical survey of modernity as instrumentalisation and of late modernity as where charity (re)appears. Then I translate this analysis into an educational challenge and its promising effects. The transition from a culture that hinges on strict instrumentalisation into one that opens up to charity has not yet been integrated in official pedagogical and didactical directives.

Results: The philosophical exploration of the cultural field shows the possibility as well as a desirability of integrating charity in (not only) higher education. Though the effects of this integration can only be considered forthcoming, a promise without any evidence, this philosophical reflection argues the probability of positive pedagogical results.

Conclusion: The reappearance of charity in culture urges education to also look beyond its modern formats. One possible initiative is the 'insertion' of charity. Reflection on a care experience is a pedagogically justifiable form of this insertion. What was deemed irrelevant, private and optional before becomes core educational challenges now. The new meaning of the world, without changing the world, is precisely this: let us keep teaching economy, engineering, law, medicine, etc., but always against the backdrop of charity.

\section{Introduction}

The argument for a (re)insertion of charity ${ }^{1}$ in education hints at the possibility of a transformation, which this journal, Transformation in Higher Education, has chosen from the very beginning, to study in its full complexity (Du Preez et al. 2016). The transformation I will defend here is not, however, 'structural'. It does not aspire a change in organisation, financing, pedagogical implementations and so on. And yet it somehow affects all of those elements. You might compare this insertion of charity with the adding of salt to a dish. This does not alter the taste, as when one replaces meat by fish, yet it intensifies the flavour. Charity does not replace any current educational system with another - it never does this to or with any system - but it reveals a different meaning of it. Within all existing educational systems, the 'sense' - all meanings of this word included shifts. The students who graduate, who 'emerge' from its system, are not other people - saints instead of sinners, martyrs instead of people next door, apostles instead of 'rich young men' (e.g. Mt 19:6-30) - but have become professionals who have acquired a taste for what is not typically or exclusively 'modern' is not completely instrumental and accumulative. They should have an eye for a beauty that is not of this world, lend an ear to an 'other' that cannot be reduced to myself, mind a truth that is not confined to science. Why and how would education have to take these traditional pillars of thought, truth, good and beauty, beyond modernity? And where does charity come in?

\section{Cultural historical background}

The rather strange and challenging, perhaps even provoking, title suggests a current lack, a privation that affects actuality. The basic contention of this article will be that modernity as the process of instrumentalisation (and accumulation) has left something valuable behind, has left something out of our educational concern with the future and with those who will inhabit it. This 'lack' now becomes visible as such, as urgency and opportunity, as challenge. Charity is more than just a pedagogical option but appears in contemporary thought as 'destined'. The appearance of charity in cultural discourse then becomes the most radical challenge to education.

1.Charity refers to neighbourly - and, of course, 'otherly' - love here, not to donations of any sort. 
Of course, modernity has been known to think about charity (Hanley 2017). But its attempts always pointed at sources like affection or reason and ended up reducing charity to sympathy or solidarity, which is definitely something else. I will maintain that charity always enjoys a religious provenance and needs this to keep being articulated.

\section{Modernity, instrumentalisation and accumulation}

The question concerning modernity is, as such, too large to be treated here. I will therefore, at the risk of being selective or even arbitrary, isolate three features that are typical of modernity and relevant to education, viz. planning, liquidity and the obsession with competences. These tendencies were, of course, not yet explicitly present and detectable in early modernity. It is only by analysing late-modern society and looking back that we can discern these tendencies as such.

\section{Planning and growth}

As is commonly accepted, modernity is marked by a process of instrumentalisation, one of many possible translations of Weber's concept of rationalisation (Weber 2004), the social echo of Descartes' methodological focus. Those who read and understand Heidegger will recognise this as an element of technology, his name for the history of metaphysics (Heidegger 1977). Many of his students have followed that line of thought (Arendt $1958^{2}$ ). The process of instrumentalisation can take many forms - let me just give some examples as they occur to me: building a just society (in the ancient Greek sense) becomes efficient managing and marketing of social atoms (liberal individualism); politics loses its vision and becomes amoral decision strategy and vote counting; morality reduces to deontology and other forms of applied ('instrumental' and 'utilitarian') ethics; juridification and formalisation of human relations; ${ }^{3}$ urbanisation, neutralisation and anonymisation of social space; measuring and predicting, production and consumption as the only way of dealing with 'things'; reduction of care to cure and of education to didactics; the transition of society into market where social atoms are further reduced to producers and consumers; the existential modesty of acceptance ('mercy') became the managerial arrogance of planning (control); the experience of advent ('wonder') became the future of extrapolation (disenchanted calculation); charity (the complex phenomenon of gift) became solidarity (investment), etc. ${ }^{4}$ All these cultural-historical 'vectors' - I hope everyone recognises these as indeed typical - of modernity interact (contaminate?) with and confirm each other. Education, for one, becomes a didactical market by turning students into clients and parents - and society itself into stakeholders (Weyns 2013). Juridification of the pedagogical relation can be discerned in the growing rate of

2.In this study, she famously describes and criticises the historical transition from action through work to labour. This transition affects everything, from art to politics. It can be applied to education also. An elaboration hereof would take us beyond the scope of this article.

3.The basic rights in terms of freedom, like freedom of religion, freedom of speech, etc. are purely formal and totally independent of what one believes, says, etc. What one believes, says, etc. is constitutionally irrelevant.

4.The term 'reduction' here is not necessarily morally loaded. legal action taken by parents against the faculty's evaluations and decisions - whereas before, parents used to collaborate with schools in the education of their children. Applied ethics demands that education meets with detectable and preferably measurable criteria and achieves 'clear and distinct' goals which is why mathematics' scores are often used to compare schools: it is supposed to be 'objective' only in that it is more measurable than, for example history; though the latter perhaps might be considered to contribute more adequately to humanitas than math. ${ }^{5}$ In Belgium, the amount (quantity again) of teaching Full Time Equivalent (FTEs) (quantity) a school can employ only depends on the amount (quantity) of students they counted during the former school year. And how about the quality of education? This may be translated into a 'sales argument': alleged quality, at least the perception of quality, is no more than an argument for clients and stakeholders to increase the number of students. ${ }^{6}$

I need to mention a second fundamental trait of modernity here, which shall remain a function of the first one for the sake of the argument of this article. It is the 'accumulation imperative', the sanctification of progress. I once accidentally skipped through the financial pages of a respected daily paper where the evaluation of a firm perplexed me. It explained that while, admittedly, the firm was 'growing', there was every reason for concern because the growth itself was not growing. I wondered how the necessity of exponential growth can be anything else than short-term suicide. This 'perversion' is not only typical of capitalism; capitalism is a typically modern economy because it thrives on this 'accumulation imperative'. From history as progress and the famous paradigm of evolution - which excludes the 'event' to marketing unnecessary new models of anything and the notion of lifelong learning - which is something else than wisdom - are all effects of this imperative. The history of philosophy as progress (e.g. Hegel and Comte) is only justified by the typically modern philosophy of history - that only served to 'prove' that modernity is the magnificent outcome of history as progress. This means that history in general and progress in particular are self-explanatory and self-justified. Late modernity has questioned this 'proof' and has revealed the tautological core of the alleged evidence of history - hence the many books and articles that have the overtly paradoxical 'after history' in their title.

The phenomenon of 'programmed instruction'7 can be considered typical of the above trends, the pedagogical echo of Descartes' focus on method. Education reduced to a technology, to planning. The whole field of humanitas is reduced to a well-defined package of knowledge that

5.Actually, as Paul van Tongeren remarks in Filosofie Magazine (2016:24[3], 10), the problem is where modern education and care want to ensure quality. But this 'ensurance' requires measurable evidence, results. Therefore, quality that needs to be ensured is unavoidably replaced by quantity.

6.There is a wonderful episode of the brilliant series Yes, Minister, 'The compassionate society', about a hospital that is fully staffed except for medical staff because there is no money for that So the hospital runs like a charm, without patients. The core is no money for that. So the hospital runs like a charm, without patients. The core even won a prize for that. (see https://www.youtube.com/watch?v=U01oual9ysQ)

7.This method was developed from Burrhus Skinners notion of 'operant conditioning' onward. 
everyone is supposed to share, the accumulative acquisition of that package is realised through methods based on conditioning psychologies, whereby the student's mind is considered a tabula rasa or at least a container that contains precisely the same content - different 'initial conditions' can be regulated by studying the social, economic and geographical backgrounds in order to 'remedy' and indeed even erase the differences. The differences that cannot be remedied (e.g. religion) have to be considered immaterial ('strictly private') and cast out. ${ }^{8}$ The whole process is again a matter of control and planning. What cannot be translated into the programme is considered superfluous by necessity. The learning and teaching experience is completely free of desire, of a healthy curiosity, of wise authority, in short of Plato's pedagogical eros. The notion of programmed instruction and the enthusiasm it enticed is typical of the American 1950s. In the post-World War, planning (Wiederaufbau) was the main cultural determinant, and since Europe was shot to pieces, literally, the United States could take the cultural lead. One may wonder if there would not have been a Second World War, would we have had behaviourism, programmed instruction, socio- and other metrics. But then again, experimental psychology started halfway the 19 th century in ... Germany. ${ }^{9}$

\section{Liquidity}

The whole idea of education being programmable is now frustrated by an unexpected effect of modernity - namely the world's liquidity - as diagnosed by Zygmunt Bauman. ${ }^{10}$ The thought behind programmed instruction is the complete integration of a predetermined set of knowledge and competences, the acquisition whereof can be measured, that is supposed to be a necessary asset to adult professional life. The problem that liquidity poses here is that no one has any idea how the world will look like in 2038. Our modern 'institutions' that have guided modern life during some two centuries are changing increasingly faster. I would illustrate this by taking marriage as an example. Since Napoleon introduced his famous code, marriage was no longer in the first place a church matter, what it had been for centuries, but became a free contract between a man and a woman. They had to answer some other (modern) criteria: they had to be free, that is, unmarried and not forced by parents or by anyone else; they had to be fully 'conscious', that is, rational and informed. Once a marriage had been arranged in the city hall, people could 'upgrade' their liaison in the church, but not before the marriage was a civil fact. The format of this 'double contract' with, firstly, the Secular community, and secondly, the faith community, held out for about ten

8. Society can organise initiatives to remedy the lack of social skills (e.g. scouting), of economic potential (e.g. grants), of proximity (e.g. boarding schools, school bus), but cannot not 'efface' religious difference. Logic operation, managing strategy, political decision does not affect religious obedience or identity. When an Indian politician suggested that all pariahs should convert from Hinduism to Buddhism in order to escape from social rejection, they bluntly refused. I cannot imagine anyon refusing a grant or a school bus ride on the ground of social or economic identity.

9.In 1879, Wilhelm Wundt 'opened' the first laboratory for experimental psychology at Leipzig University, which was supposed to move psychology as a hard core science away from philosophy (and theology).

10.Zygmunt Bauman, Liquid Modernity (2000), Liquid Love (2003), Liquid Life (2005), Liquid Fear (2006), Liquid Times (2006) and finally Liquid Evil (2016). generations. Marriage meant the same for our parents as for their parents and so on, all the way back into the early 19th century. But now this format is changing so rapidly that even during one lifespan, within one generation, it changes significantly. In many states, civil divorce has been commonly accepted and now same-sex marriage. ${ }^{11}$ In some states, samesex partners can adopt children. All this changes the whole concept of family - which, by the way, according to some, is precisely the ideological anti-Christian and anti-traditional strategy underlying this legislation. We can say the same about tax regulation, traffic law, the prices of bread and houses (the 'trigger index number' is a tool to make this change acceptable), etc. This asks for a different way of 'coping', of 'relying' than in (early) modern society. ${ }^{12}$

I can indeed say 'modern society', as liquidity is considered Bauman's qualification of postmodern society. If we confine ourselves to the moral and legal 'aspects' of postmodernity, to the normativity in present society, then we can easily discern a major change that renders this society incomparable with all former versions: the rejection of authority. 'You cannot do that there!' simply does not work anymore because of a complete lack of unanimity on most socio-ethical matters. When I asked a young boy to remove his dirty boots from a bus seat, he came back with 'Do you own this bus, maybe?'13 There is no moral argument that stretches beyond the individual. But then again, the 'individual' in its modern sense does no longer exist, the rational subject has gone. Ethics has gone 'tribal' (Maffesoli 1996). It has become a code that has its validity only within certain subcultures and cannot sustain itself over several generations and become 'tradition'. Liquidity is modern in that it does not even - or no longer - have to reject tradition, it prevents it.

This 'code' is already something else than the codes that were disposable in the 1960s. Then the code was simple: accept (civil code) or reject (hippie code) the one existing code what United States president Nixon called the 'moral majority'. Now there is no longer a default code that one can relate to. This is by no means a youth strategy. Communication, to name but one example, has changed so rapidly - through industrial processes during the former generation - that this demands an idiosyncratic moral code ('netiquette') that cannot be shared by grandparents who do not have a Facebook account.

This means that a large part of 'young morality' escapes the notice of those who are in charge of education. They simply

11.l remember, when I was young, there was this joke that went 'Last Sunday, two men got married in our church.' 'WHAT?' 'Yes, one at 10 o'clock and then another

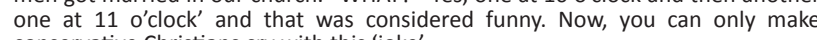
conservative Christians cry with this 'joke'.

12. Of course, not all of these changes are ideologically motivated, like the legislation concerning marriage - although the way divorce has been facilitated lately can be seen as an ideological attempt to undermine the (Christian) notion of the family as the cornerstone of society. But legislation that concerns bioethical matters, like abortion and euthanasia, certainly is. Also, one could see how the way the finartion and euthanasia, certainly is. Also, one could see how the way the financing of mental health care significantly shifts from residential to ambulan might hide a strategy to diminish the impact of catholic congregations who have
been engaging in resident care for ages.

13. When I was their age, we knew it was 'not done' to place dirty boots on a bus seat, and we expected elderly people to reprimand us; otherwise the act would lose its character of 'rebellious statement'. Now, it seems just a matter of complete indifference. 
cannot understand the code that 'communicates' that morality within those spheres where this code is evident or valid. Nor can they communicate their code as valid, it is simply not accepted. The only way out of this, the only 'cure' against liquidity, is authority (Verhaeghe 2015). Of course, I do not mean dictatorial control, but rather the 'quiet authority' of someone who gets all due attention without explicitly having to ask for it.

\section{Competences}

Our school system (in Belgium), and indeed our culture in general, has become obsessed with (technical) competences as the modern compensation for or even alleged emancipation from the more traditional 'content transfer'. The problem with this is that the schools hand over youngsters to society who are capable of almost everything, but lack the social and moral imperative, let alone the 'desire', to actually apply those competences. The reduction of the final end of education, viz. to build a good and just society, to a mere ticking off of external, measurable criteria fails to meet the fundamental requirements and problems of current society. These criteria, moreover, are dictated by current industry, as, e.g. the Browne report shows (Collini 2012 ${ }^{14}$ ). All that industry requires is indeed a set of competences - industry itself will take care of the content input after the competences have been mastered. The subject that gathers these competences should not be motivated by morality but by the need to survive in society or by plain greed. Industry thrives on this. And yet, at the moment when traditional economy and industry are challenged by this (sociological) 'revolution', named sharing economy, the same industrial and financial world, in 'crisis' because unable to maintain itself according to its own basic principles, commands government, in its turn unable to control the aforementioned world, to force these principles onto education and care institutions. Here is some ugly perverse mechanism at work that hampers education - and care.

Not only did the curriculum shift from content to competence, but the faculty also experienced a similar shift. Nowadays, didactic technological skills are considered more important than general cultural content. No teacher or professor is supposed to know who Vivaldi or Beethoven, Breitenbach or Coetzee is, what the Universal Declaration of Human Rights or the French Revolution is all about. Teachers have become technicians. Cultural embeddedness, however, a source of the aforementioned authority this may be, has (silently and implicitly) been declared obsolete. Even religious education prefers pop songs to Bach's Passions. And that has also to do with the 'associative' method that I tried once, never to call upon it again. This method says you should always start from the experience of the students, their 'living world'.

14.This British report from 2010 states “ Higher education matters because it drives innovation and economic transformation. Higher education helps to produce economic growth, which in turn contributes to national prosperity'. See www.gov. /government/uploads/_ystem/uploads/attachment_data/fle/422565/bis-101208-securing-sustainable-higher-education-browne-report.pdf (visited 14 March 2018). The link www.independent.gov.uk/browne-report, mentioned in this pdf-document, does not work.
I found it difficult to lead my students away from their world - though this is what the Latin e-ducere means. A completely different method proved to be more fertile: throw them into a completely new world - with this notion of 'code' at the back of our thoughts. I took my students to an abbey - a completely different 'code'. They loved it! Not because it was catholic, but because it breathed religion (in its broadest sense) and as such, contrasted favourably with the liberal, neutral, industry-driven, achievement-orientated and individualist-mechanical format of their daily life in modern society.

Education finds itself therefore confronted with three challenges: facing liquidity, thinking beyond (mere industrial) competence and instrumentalisation, and re-inserting charity. These three challenges mirror the three great metaphysical topics: the true, the beautiful and the good. Facing liquidity refers to the Heideggerian historical-destinal understanding of truth; thinking beyond instrumentalisation means opening up to what is meaningful without being useful; (re)inserting charity requires a rediscovery of a Platonic-Augustinian approach in thought. I will come back to this later, when I quote Ignace Verhack on the challenges to catholic education.

\section{Late modernity and charity}

\section{Cultural experience}

In an instrumentalised world, charity is not everything. Last year I underwent some heavy surgery when 'they' performed a pneumonectomy. Now, the first interview with the surgeon was interesting. With gleaming eyes, one hand holding a pen and drawing a lung that looked like a clumsily poached egg and with the other making cutting and stitching gestures, he told me how he would cut me open, spread my ribs, rip out the lung, staple the remains and so on, suddenly pausing to take an inspired note reminding him that he still had to order some blood, in the way one writes 'milk' with a circle around it on a shopping list. I remember thinking 'Am I really going to put my life in the hands of this butcher?' and replying a little later 'Yes, because this is a technical routine for this noble and renowned craftsman!' And so it turned out to be. A marvellous piece of work. The only charity involved here was that the surgeon worked for $5 \mathrm{~h}$ to make it technically perfect without rushing it, realising that he would earn exactly the same enormous amount of money if he did the thing in under $4 \mathrm{~h}$.

I am truly grateful that the surgeon completely ignored the symbolic or religious purport of my - or of course any other patient's - body, which might well have given him stage fright. A problem arises when the instrumentalisation of the body becomes the only way of physical interaction or even intimacy. The 'pornification' of the body may well be a symptom of this. Once I participated in a Relational and Sexual Education session with 14-year-olds. It was awful. Only the technical aspects were treated: how penetration worked and what kinds of contraceptives were available. Not a word about the value of sexuality or its place in a 
solid relationship. The 'inter-' in intercourse was purely utilitarian - to distinguish it from masturbation, presumably and utterly mechanical. ${ }^{15}$ Cartesian sex.

In Flandres, a centre for personal training offers the following programmes. ${ }^{16}$ When you are alone, you may benefit from course one - How to meet other people. When this works, you can attend course two - Engagement training. Suppose you are in love, there is course three-Marriage counselling. In case your marriage threatens to fail, you can rely on course four Marriage repair. If your marriage actually fails, turn to course five - Successful divorce. And then you can go back to course one. The message of this centre is simple: life requires professional technical instruction. Do not trust your own common sense or your nearest and dearest to help you live your life. It is as if we cannot learn anything from tradition, from our parents and our peers that is worthwhile without becoming technological and professional. All this instruction is, of course, well meant and very useful, but there it stops. Usefulness as a modern ethical imperative is not questioned here, it is taken for granted. ${ }^{17}$

This instrumentalisation, the total immersion of culture into technology, has 'discouraged' many people, young and old. The absolute priority of use has obscured the desire for sense that motivated thought before (and after?) modernity. As psycho- and other therapies took over from religion, something disappeared: the 'meaning of it all'. The external reference, from the caricature of a God with a long grey beard in a white dress to the most subtle religious imagery, died out-as prophesised in Nietzsche's autopsy of God (Nietzsche 1974, §125). Modernity - i.e. the victory of enlightenment over its reaction, romanticism - reduced the 'meaning of it all' to the scientific explanation of the world. In a not completely fathomable way, science succeeded in positioning itself as the modern evidence. The scientific explanation is better than any other because it is scientific. But if this world 'encloses' on itself, around certainty, power and success, society breeds burn out, depression and delinquency. In his lecture at the first academic opening of my project ZIeZO (organisation of reflection retreats for students), leading youth psychiatrist Peter Adriaenssens pointed this out. ${ }^{18}$ He significantly added that education has its responsibility here. If it merely 'delivers' young people who are only fitted for industry, if it only serves as an instrument to generate competences and transfer scientific facts, if it forfeits

15.The school doctor was surprised when she told the 14-year-old children that doctors were no longer obliged to notify the parents when a girl of their age asked for a 'morning after' pill and I told the class that I utterly regretted this, since I was for a 'morning after' pill and I told the class that I utterly regretted this, since I was
convinced that in such situations the parents, after an understandable moment of
frustration and anger, would only turn out to be the only possible support. I do not consider ignoring the parents in such situations a victory, as the school doctor initially did. Later on, she agreed with me.

16.For reasons of discretion, I will not mention the name of the organisation.

17.This utilitarian ethics has recently developed into an ethics of sterility. In an illustrated weekly, a respected journalist wrote that a hand shake is no longer accepted, since you actually rub each other with bacteria. Even a high five has accepted, since you actually rub each other with bacteria. Even a high five has become dubious. We should all follow the example of former president Obama and confine ourselves to a 'fist bump'. In an academic journal, I read of a doctoral student in medicine who could not understand how parents still allowed their children to blow out candles on a birthday cake, since that was no less than injecting bacteria into the cream. Sterility beats tradition. constructive cooperation with society, then education is no more than a machine for varieties on programmed instruction. Those responsible for the organisation of curricula should be convinced of the necessity of a 'humanisation' that reaches beyond mere 'instrumentalisation'. His view has been confirmed at a conference organised in 2012 by VSKO, at that time the Flemish umbrella organisation for catholic education, showing that voluntary work leads to less depression and burnout. ${ }^{19}$

While governments seem to 'restyle' education according to current economic imperatives, (Christian) scholars point out that this 'instrumentalisation' of society and its youth neglects several fundamental human values. Education that narrows itself down to the transmission of competences and the 'spirit of achievement' leaves no room for voluntary work as this has nothing to do with competence nor achievement, at least not at first sight. ${ }^{20}$ There is no scientific evidence for the 'use' of voluntary work - only statistical covariance with measurable and definable feelings of satisfaction, comparable with the feelings that paid work yields.

One of the notions that lost its cultural ground because of instrumentalisation and the subsequent suppression of educational desire was indeed charity. Doing something for others without explicitly expecting something in return became a stupid thing that neither economy could defend nor (social) psychology could explain. Neo-Marxists even considered charity counterproductive and hypocritical because it was nothing more than a strategy to hide the injustice that was kept alive at the roots of society by precisely those who practiced charity - i.e. Christians. The fact remains that no human science, typical product of modernity, can explain or justify charity. Even altruism is unmasked as social egoism. This is why charity never really 'escaped' from (moral) theology where it was generally agreed to belong.

There is even a political motif that shows how and why charity, neighbouring love, remains a marginal value in modern society, even though it is one of the three pillars of modern, enlightened political thought: fraternité, together with liberté and égalité. One can read this in the very first article of the Universal Declaration of Human Rights. It proclaims that:

All human beings are born free and equal in dignity and rights. They are endowed with reason and conscience and should act towards one another in a spirit of brotherhood. ${ }^{21}$

This means that liberty and equality are treated as structural evidence, but charity belongs to the moral register. This further implies that, unlike charity, liberty and equality can easily be 'formalised', translated into a consistent jurisdiction and a political ideology that have to safeguard them.

19.Unfortunately, as VSKO does no longer exist, the documents are no longer to be found on the Internet.

20.The care experience implies a total absence of technical or professional activity. There is no goal or result that has to be achieved and that is not the experience (of bliss?) itself.

21.See www.un.org/en/universal-declaration-human-rights 
More and more, society finds itself unable to integrate charity into the mechanisms of the modern nation-state because, while law is obligatory, morals are not. Nowadays, political thought only deduces its insights from the two premises of liberty and equality. This yields a society where everyone can be the congenital egoist one is by nature, a social atom, an island that must not harm anyone else and must not be harmed by anyone else. Law takes care of that. As modern philosophical political thought has it, since Hobbes, the state has to curb natural egoism - homo homini lupus - and that warrants the survival of individuals as citizens in a society (Hobbes 2011). A cold, sterile and mechanical society, but still a society. Political voices that allow for religious motivation defend another 'model'. They will have it that, as all religions really aim at peaceful living together, they should inspire a common moral pre-political motivation to that effect. ${ }^{22}$ The basic requirement here is decency, not power or anything like it. Decency can be considered the 'stepping stone' to charity. A young fellow who takes the bus to a political meeting but does not give up his seat to an old lady is not a decent member of society.

Still, charity lives on in our societies. A major study in the Netherlands showed how patients and their relatives and friends appreciated charity in (catholic) hospitals but remained almost totally indifferent as to what motivates this charity (Dresen 2002:3-14). Even capitalist industry thrives on charity, a fact that can be detected during a work-to-rule action. When all employees start doing nothing more or less than what their contract (juridification) and deontology (applied ethics) require, then the firm or institution shows a slowdown or decrease in productivity or fails to maintain a certain level of service. The inability of traditional economy and also of socio-liberal politics, high level education, sociometrics, etc. - to deal with this 'moral margin' is just one more symptom of this instrumentalisation. Charity, the 'favour' for free, with nothing expected in return, remains invisible in the industrial equations that determine the understanding of labour. This symptom has recently produced another symptom that 'contaminates' traditional economy, namely sharing economy, also called peer-to-peer or collaborative economy. It is intrinsically social (regional) and ethical (ecological) but presupposes, as platform economy, high IT-performance that requires current cultural 'digital presence'. What happened to Uber and Airbnb is of course also symptomatic, not of the instability of traditional industrial models but rather of their persistency. To some, sharing economy is where ethics are (re)inserted in capitalist economy. But still, in the same way as above, someone who takes the bus to a picking farm or a repair café and refuses to give up his seat to an old lady scores zero on the moral scale (Comte-Sponville 200123). Ethics still remain an option here,

22.It is fundamentally wrong to state that religion and violence always go together We can follow René Girard where he discovers the violent roots of religion and we also follow those who point at the relation between actual violence and religion. Inasmuch as that relation is genuine, it always turns out to be a perversion of that Inasmuch as that relation is genuine, it always turns out to be a perversion of that religion. Let us not forget, for instance that Muslim terrorists barely know the Coran and who they, once welcomed into ISIS, only receive military training and no
more religious indoctrination.

23.Politeness, he suggests, and decency are themselves perhaps not real virtues, but they certainly are the indispensable conditions of virtuousness. Without them ethical virtues remain empty. which is why sharing economy shares the same problem with competence education.

\section{Philosophical reflection}

It seems that technology, including scientific explanation, has somehow reached its limits, has exhausted its potential (Heidegger 1978:374-377). This is the whole philosophy of the 'end' of metaphysics, the 'end' not being a historically or scientifically established end. This 'end' contains the (re) appearance of charity in thought, in culture. The late-modern interest in charity does not stem from an anachronistic strategy to 'rewind' modernity, but on the contrary, to think through modernity by 'breaking' the rationalist imperialism. It would indeed be charitable for thought to allow for other than strictly rationalist discourse. By removing the primacy of scientific argumentation from philosophy and maintaining this argumentation as a meaningful narrative amongst others, equally valid in their truth claims and free from the complacent system of objectivity, thought would finally recognise the sense of a movement that has been working its way through Western culture since the end of the 19th century. ${ }^{24}$

In a technological world, it is not wrong or bad or evil to think technologically. This is what Heidegger meant with Gelassenheit (often translated as 'releasement'); you can only say 'yes' and 'no' to technology (Heidegger 1966). One can neither reject it nor can one overcome it on one's own initiative. It is historically destined. We have no choice, the world that has been given to us is a technological world. But we should not succumb to it. The notion that our world is finally and ultimately the only true one has been criticised from all sides, for example by Nietzsche, Spengler, Popper and of course Heidegger. It is therefore just possible that each world (or cultural epoch) reveals its own flaws and inner discrepancies at the moment of its crisis. And if there is one word that has come up in French thought, trying to grasp beyond traditional Western thought, it unquestionably is 'other', the 'other' that cannot be totally recuperated and reduced to the 'same'. If Hegel's system as the total recuperation of anything 'other' is typically modern, then late modernity is the denial of this 'totality'. The 'other' resists recuperation, reintegration and reduction to the self.

How can this 'other' remain truly other in a technological society that hinges on control, planning and extrapolation? When I press the light button of my reading lamp, I do not expect charity from the bulb or from a deity that helps readers. This is technology, as realised through science. The problem is not that we should skip science and technology in a nostalgic or rebellious mood. We should acknowledge that science and technology are not everything in an ultimate sense, that they can perhaps define their own 'total', viz. the scientific world, but that this 'total' is never a Hegelian identity with the one and eternal 'world' or 'truth' or 'reality' - words that all

24.1 refer to the famous Methodenstreit, Kierkegaard's and Nietzsche's criticism of Hegel, the appearance of psychoanalysis and quantum mechanics, the tradition that Heidegger 'started', etc. 
become problematic when we leave the scientific (in the sense of Hegel or of science itself) system of objectivity.

To give an example that comes from the religious world: Holy Unction or Anointing. What does this mean, even philosophically? It is not a trick where magic ointment will compel God to cure a patient in a miraculous way that would stupefy the medical world and urge the Pope to canonise someone. No, the moment when the doctors declare themselves baffled and leave the room, we light a candle and send for a priest. Why (Meganck 2016a:473-498)? Because when technology fails and leaves us in total despair, from another angle or perspective hope rises. Hope is despair seen from a non-technological position - following Christ up the mountain (Mt 5:1). Hope is where thought recognises its religious roots. Late modernity is precisely the point where thought stops rejecting this recognition.

In a refreshing conference, organised by Christen Forum, on the fundamental challenges to catholic education, Ignace Verhack (emeritus professor of Philosophy at the Louvain Institute of Philosophy) formulated three of them - that turned out to refer to the three traditional themes of metaphysics: truth, good and beauty. ${ }^{25}$ But he introduced them without the recuperation imperative of traditional metaphysics. Instead, he followed the 'step back' that Heidegger advocated (Heidegger 1969:49). Catholic education is not just a matter of evangelisation. It should show, point at, open upon the possibility of what lies beyond the world of science, of law, of efficiency. It should turn the world of explanation (quod erat demonstrandum) into a world of appeal ('Listen, Israel' and 'You have heard ... but I tell you ...'). It should offer a 'spiritual vocabulary and grammar' that at least allows young people to see beyond the world of science, and make a choice. Here, for example suffering would be understood as an appeal instead of reduced to a (scientifically established and diagnosed) problem that could and should, but is not being (technically) solved by therapy, and when therapy fails, euthanasia.

It was Gilles Deleuze who famously remarked that Plato was an ethical thinker in the first place and that his ontological and epistemological thought derives from that basic inspiration. I would rephrase that insight here as follows. As the basic miracle of the world consists in the fact that we can understand it, philosophy is all about understanding well. Therefore, it is our moral duty to safeguard understanding and to keep thought 'clean'. The way in which Plato tried to do this is less relevant here. It is about our moral duty to think and to think well. When modern philosophy deals with 'thinking well', it speaks of method and clear concepts, rejecting tradition and prejudice - prejudice entailing also religion. ${ }^{26}$ But according to Plato, understanding was a present of gods, a divine gift. ${ }^{27}$ Therefore, the correct moral 25. Unfortunately, I am unable to find the exact date of this conference.

26.As Gadamer famously remarked, typical of modernity is its prejudice against prejudices.

27. He used theos, theoi as well as theios to denote the divine arrival of thought in man. Perhaps this might have been his real problem with the sophists, not that they used rhetoric, but that they should consider themselves the owners, the makers of truth instead of recognising a more religious source of thought, of truth. attitude re epistemology is not method, but humility and gratitude. This is what Plato, of whom Whitehead said that all Western philosophy can be read as a footnote to his work, has taught us, not that man has a dual nature and the rest of textbook-Platonism. ${ }^{28}$

It should not be considered accidental that both Plato, who opened the door to metaphysics without actually stepping through, and Heidegger, who opened the same door to allow metaphysics to leave without actually following its disappearance himself, should consider gratitude so essential to thought. Augustine, Christianity's own Plato, also posited (Christian) love (so: charity) in- and outside the order of being and knowing, where also Plato's 'Agathon' is to be (dis)located. Charity, Augustine says, works its way through thought without being determined by reason. ${ }^{29}$ To 'describe' this (dis)location, one needs poetry instead of logic. Anselm came, I think, closest to achieve this. He spoke of God as the Highest entity one could think. This is indeed the metaphysical Highest Being or Highest Idea. But then, at the same time, he also says that God is greater than all that can be thought. So, God is at the same time the ultimate reference point of the whole thought system and the point where thought 'loses' itself. God is also where thought stretches beyond its own boundaries. The strongest element of metaphysics has therefore always been its weakest - and this is a biblical dynamics, no less. God is, metaphysically speaking, the point where metaphysics lets go of its absolute (Aristotelean) form, this self-emptying being de-exaltation to the Holy Name - the name that has no corresponding being and is therefore holy (Phlp 2:5-11; Meganck 2015:211-224).

The point I am trying to make here is that the insertion of charity (gratitude and mercifulness) at the heart of thought, of philosophy - whether the academy is ready for it or not is a move 'beyond' traditional metaphysics that complies with the undercurrent that critique of metaphysics has been following now for over a century. It has become an 'open' thought because the cork, namely the absolute, the total, the Highest, has worn off. In the words of Nietzsches madman, God is dead. And whereas many academic philosophers fulminate against this critique because it threatens to kill thought, the critique replies that it is precisely traditional metaphysics that is suicidal, wanting to enclose the world into its one and final (scientific, logical, conceptual) explanation.

The 'good message' of philosophy consists in the experience that we do not have to bend the run of history to welcome charity in thought. We can detect traces of an emergence that can only be called promising. Firstly, 'charity' and similar terms have entered the philosophical discourse without real

28.'The safest general characterization of the European philosophical tradition is that it consists of a series of footnotes to Plato' (Whitehead 1978:39).

29.Augustin said 'Love, and then do whatever you want'. No harm can ever come from real love. Now, within the sphere of logic, 'anything follows' only applies to a false proposition (a contradiction). So, in order to prevent charity from becoming the proposition (a contradiction). So, in order to prevent charity from becoming the
contradiction at the core of Christianity - more or less in the way Freud called Christian charity a perversion, a sort of psychological contradiction - and thereby Christian charity a perversion, a sort of psychological contradiction - and thereby
perishing in what is called a 'deductive explosion', we should think of it beyond the reach of logic. 
headstrong resistance. Secondly, charity no longer exclusively belongs to (moral) theology anymore. It is Gianni Vattimo who remarks that charity is now generally accepted as a genuine philosopheme (Vattimo 1997:40, 46-47; 1999:64). Continental (French) as well as analytic (English) philosophers courageously study charity. It should be noted here that this happens almost exclusively within a tradition that has become known as the critique of metaphysics.

Leaving aside Kierkegaard, who famously launched his criticism of Hegel from (more or less) the same Christian background that both thinkers shared, we start this tradition with Nietzsche. Very significant but hardly noticed here is his preface to the second edition of his The Gay Science. There, he mentions the three theological virtues, but not in connection with God but with the delivery from metaphysics as a salvation to be compared with a physical healing (Meganck 2016b:154-170). I contend that this introduction of charity, hope and faith in philosophical thought is all but coincidence, a literary effect or an unhappy metaphorical reference. When thought reaches beyond traditional metaphysics without actually destroying it, it cannot but meet the cornerstones of its very provenance, viz. Christianity. The new configuration or constellation where philosophy and theology find themselves in today is more than just an academic, speculative exercise. The 'theological turn' (Janicaud 2000) of history cannot be ignored as a failed strategy of a handful of devout philosophers, sharing a phenomenological background, in France (Jonkers 2005). It has become a cultural event, announced in the work of Marcel Gauchet.

\section{Educational experience}

The possibility of this above-mentioned new configuration is implied by the political question concerning the place of religion and philosophy in public debate. While modernity seems to have decided that these discourses should remain within the private sphere, late modernity obviously no longer holds this to be evident. Recently, (non-functional) identity religious or not - has become an item on the socio-political agenda. Catholic education could not prevent, even if it wanted to, the shift of 'identity' from evidence to problem. Schools found themselves challenged to articulate their 'catholicity' (Meganck 2018:30-46).

This has to do with secularisation, broadly understood. In modern society, every single life span used to take place within one and only one ideological 'pole'. Catholics went to catholic schools, catholic youth organisations, catholic pubs and catholic hospitals, they were a member of catholic unions, catholic health insurance companies, even played in catholic football clubs and ditto brass bands. The same holds for socialists and liberals, respectively. Those barriers eventually fell down to make place for a religiously and philosophically indifferent and neutral society.

Some scholars defend a connection between this indifference and rather disquieting symptoms like depression, burnout and radicalisation. Recent study in Belgium shows that there is an alarming rise of antidepressant medication intake by children between 11 and 15 years old. A society that 'removes' all religious or philosophical safety nets and replaces them by industrial imperatives actually creates the above-mentioned symptoms. The 'growth model' that motivates industry lays a heavy burden on the frail shoulders of youngsters. More is never enough. In the financial reports, one can read that firms that achieve growth, but whose growth itself is not growing, that is, who do not achieve exponential growth, fail to meet market requirements. This shows an inner perversion at work at the heart of industry. It is, again, this perverting industrial logic that, through helpless politics, determines education. Not only do schools find themselves compelled to organise their institute according to this logic, as noted above, but the same logic is systematically infecting the school curriculum.

Young adults who should acquire social skills and competences, which are sadly lacking in the curricula, are confronted with levels of achievement that only the very best can ever hope to reach. So, the rest just 'drops out'. This is all the more sad because every teacher has known pupils who were rotten at math but had a heart of gold ...

Secularisation seems to be the term that connects the promotion of the above logic and the diminution of religious impact on society, including education. In Louvain, the Jesuits organise an 'open year'.$^{30}$ Whoever considers taking up university studies can apply. The students are supposed to 'taste' some courses, engage in community life (including prayer) and in voluntary work. This formula is very successful. Students testify of its positive effect. Only the above logic can prevent this formula to become the default first academic year from now on. If one could ignore what I called the 'industrial imperative', one would only find arguments in favour of such system.

It is high time for education to reflect - also literally curb this tendency. Firstly, instead of allowing government to force schools to apply the perverse industrial logic while reducing funds, school should force government to treat education as its most important investment and leave industry and banks to solve their own problems. But this is not what this article is about. Secondly, the curriculum should reverse its 'industrialisation' and formulate a new teleology. This teleology should not be elaborated in terms of production or consumption and formal (i.e. liberal) citizenship.

\section{Educational challenge}

Decades ago, in catholic higher education, students used to go to an abbey and reflect on faith as such. As an effect of what was generally perceived as secularisation, this formula was replaced by other, more socially orientated initiatives. But for one reason or another, these initiatives, once amputated from their traditional and religious - two mutually contagious notions - provenance, soon 'deteriorated' into group survival 30.https://www.kuleuven.be/studentenvoorzieningen/kot-leuven/residenties-cerab/ dondeynehuis/project 
trips or even just plain sport events. This can easily be perceived as a symptom of the above-mentioned secularisation with its - not necessary or intrinsic - implication of (religious) indifference.

Precisely because of the negative connotation of indifference, a fresh approach to the notion of 'retreat' was required. It would have to appeal to students and yet have all the spiritual effect that catholic (or indeed other religious) education is supposed to provide. As the old formula has fallen out of grace, so to speak, education should start from the premise that a retreat should not 're-treat' God but needs to hinge on an existential experience that is strong yet not spectacular. Reflection should 'root' in the world and 'grow' towards God, not the other way around (anymore). This latter, deductive approach has lost its absolute validity. As Ignace Verhack says in his latest book, Christian faith and thought have become impossible without a positive attitude towards the world (Verhack 2016). Its acceptability depends largely on a world opening up towards God, a world that is no longer deductive in that it derives its meaning from a scholastic understanding of creation.

Actually, projects such as this have many 'advantages'. There is of course the mere experience of caring that would serve as the starting point of a spiritual reflection - which will be explained in the appendix below. This is the main target of this initiative. There is also the positive effect of someone who is 'left out' of social interaction getting a (voluntary) visitor instead of a (paid, professional and technical) care taker. But it also means that suddenly those 'marginal categories' (the 'poor') regain their legitimate presence in society, just by being seen and heard again, not because of any (spectacular) achievement. Finally, it shows youngsters the hardness of work in the 'soft sector' and leads to respect for (professional) care givers.

In the 1970s several social developments generated the phenomenon of institutes for the so-called 'target groups'. This would ensure specific treatment for those who needed it. Because of this specificity, the institutes were deemed more human than the households who could only offer a family life that was often unable to function satisfactorily because of the special care some household members required. That care would now be taken over by professionals. Despite all the good intentions and the benefits of professional care on specialised sites, this development literally removed those persons that needed special care from the spheres where daily life was lived by 'normal' people.

Government is now taking initiatives to 'remedy' this situation, and launches projects that encourage 'inclusion', 'responsibilisation', 'socialisation of care', etc. And indeed, at the surface these projects seem to be meant to give the elderly, the disabled and psychically troubled persons their social rights back, but unfortunately they often are nothing but 'tighten the belt' measures. Inclusive education is cheaper than special education, responsibilisation and socialisation usually means that next of kin can pay for the extra care someone needs.
Until further notice, care is still institutional and mentally disabled persons, persons who suffer from dementia or psychic problems, are still 'strangers' in our society. There are still lots of work to be done about their 'stigmatisation'.

\section{Appendix: The gain: Psycho-ethical effects of charity in education}

Youngsters profit from a care experience on several levels (Burman 2013). On an affective level, a student 'meets' another human being 'behind' the label. It is perfectly natural to be lightly nauseated by the very idea of mentally handicapped persons, psychiatric patients or demented elderly people. Our society does not breed saints that easily. Even St. Angela da Foligno experienced traces of nausea when washing lepers. ${ }^{31}$ We are so used to live in a sterile social environment that the sight of someone who is constitutionally unable to keep up with current hygienic standards by himself or herself can only be disturbing for a youngster who has never been confronted with this phenomenon. This new world is strange and this experience is what theology calls a 'desert experience' and psychology calls 'deep water'. It is not what one seeks from oneself, which is precisely the main reason for this project. Our experience, however, ensures us that discomfort, fear and even disgust will eventually turn into something beautiful, namely the recognition of an unalienable human dignity.

On a cognitive level, students acquire a social awareness, mainly in terms of responsibility - going from merely keeping their appointments with an institution to understanding the fact that someone is actually counting on them to just 'be there'. Also, the students are able to criticise prejudices and caricatures in society and commercial media. They acquires insight in causes, mechanisms and effects of different systems of deprivation (disability, psychiatric problems, poverty, addiction, etc.). This way, they understands that those people are not to blame for needing care and help.

On a moral level, one sees voluntary work as meaningful experience and is motivated to apply the social competences above as part of life, to integrate this experience as co-determining life choices (study, profession, relation, vocation) and to recognise religious thought and ditto reflection as proper motivation for charity.

Important here is the way cognition is integrated in other faculties like disgust, responsibility, empathy and respect. 'Humanity' as a category is 'broader' than mere competence acquisition or content saving.

\section{Conclusion}

Late modernity is where thought, culture and philosophy explore the limits of instrumentalisation. By weakening the modern imperatives, charity - hitherto confined to (moral)

31. When she caught herself being nauseated, she actually ate a piece of leper skin floating in the tub, as punishment, but was then blessed with the sensation skin floating in the tub, as punishment, but was then blessed with the sensation
of receiving the Body of Christ, in the consecrated form of a Host of flesh. Most students do not go that far as this mystic nun. 
theology - reappears in cultural discourse without resistance. This urges education to also look beyond its modern formats. One possible initiative is the 'insertion' of charity. Reflection on a care experience is a pedagogically justifiable form of this insertion. What was deemed irrelevant, private and optional before becomes a core educational challenge now I hope. The new meaning of the world, without changing the world, is precisely this: let us keep teaching economy, engineering, law or medicine, etc., but always against the backdrop of charity. Education should come from the heart, as Plato would have it. This way we may make liquid society heaven on earth.

\section{Acknowledgements Competing interests}

The author declares that he has no financial or personal relationships which may have inappropriately influenced him in writing this article.

\section{References}

Arendt, H., 1958, The human condition, University of Chicago Press, Chicago, IL.

Burman, M., 2013, 'De zorgervaring van jongeren die deelnamen aan ZleZO; Een kwalitatief-hermeneutische exploratie', Dissertation presented in fulfilment of the requirements for the degree of Master of science in Pedagogical Sciences, Supervision Prof. Dr. Stefan Ramaekers; dr. Erik Meganck.

Collini, S., 2012, What are universities for?, Penguin Books, London.

Comte-Sponville, A., 2001, A small treatise on the great virtues, Metropolitan Books, New York.

Dresen, G., 2002, 'Oefening van liefde: Inhoud en publieke betekenis van een caritasethiek', Tijdschrift voor Theologie 42(1), 3-14.
Du Preez, P., Simmonds, S. \& Verhoef, A., 2016, 'Rethinking and researching transformation in higher education: A meta-study of South-African trends',
Transformation in Higher Education 1(1), 1-7. https://doi.org/10.4102/the.v1i1. Transformation in Higher Education 1(1), 1-7. https://doi.
2thejournal.org.za/index.php/thejournal/article/view/2/9

Hanley, R., 2017, Love's enlightenment: Rethinking charity in modernity, Cambridge University Press, Cambridge.

Heidegger, M., 1966, Discourse on thinking, Harper \& Row, New York.

Heidegger, M., 1969, Identity and difference, Harper \& Row, New York.

Heidegger, M., 1977, The question concerning technology, and other essays, Garland Publishers, MI.

Heidegger, M., 1978, Basic writings, Routledge \& Kegan Paul, London.

Hobbes, T., 2011, Leviathan (revised edition), Broadview Press, Ontario.

Janicaud, D., 2000, Phenomenolgy and the theological turn: The French debate, Fordham University Press, New York.

Jonkers, P. \& Welten R. (eds.), 2005, God in France: Eight contemporary French thinkers on God, Peeters, Leuven.

Maffesoli, M., 1996, The time of the tribes: The decline of individualism in mass society, Sage, London.

Meganck, E., 2015, 'In godsnaam: Een filosofisch parcours', Nederlands Theologisch Tijdschrift 69(3), 211-224.

Meganck, E., 2016a, 'Spem in Aliud ... What May I Hope For?', Ethical Perspectives 23(3), 473-498.

Meganck, E., 2016b, 'Ratio est Fides: Contemporary philosophy as virtuous thought', International Journal of Philosophy and Theology 77(3), 154-170. https://doi.org/ 10.1080/21692327.2016.1221356

Meganck, E., 2018, 'Re-telling faith: A contemporary philosophical redraft of Christianity as hermeneutics', New Blackfriars 99(1079), 30-46. https://doi.org/10.1111/ nbfr.12184

Nietzsche, F., 1974, The gay science, Random House, New York.

Vattimo, G., 1997, Beyond interpretation: The meaning of hermeneutics for philosophy, Stanford University Press, Stanford, CA.

Vattimo, G., 1999, Belief, Stanford University Press, Stanford, CA.

Verhack, I., 2016, Een weg naar God voor deze tijd, Betsaida, 's-Hertogenbosch.

Verhaeghe, P., 2015, Autoriteit, De Bezige Bij, Antwerpen.

Weber, M., 2004, 'Science as a vocation', in D. Owen \& T. Strong (eds.), The vocation lectures, pp. 1-3, Hackett Publishing Company, Indianapolis, IN.

Weyns, W.; Estor A.; Geudens S. (eds.), 2013, Marktisme: Kritiek op het berekenende samenleven, Pelckmans, Kapellen.

Whitehead, A.N., 1978, Process and reality, Free Press, New York. 